(c) American Dairy Science Association, 2005.

\title{
Evaluation of a Real-Time PCR Assay Quantifying the Ruminal Pool Size and Duodenal Flow of Protozoal Nitrogen*
}

\author{
J. T. Sylvester, ${ }^{1,2}$ S. K. R. Karnati, ${ }^{1,2}$ Z. Yu, ${ }^{2}$ C. J. Newbold, ${ }^{3}$ and J. L. Firkins ${ }^{1,2}$ \\ ${ }^{1}$ Ohio State University Interdisciplinary Nutrition Program (OSUN), and \\ ${ }^{2}$ Department of Animal Sciences, The Ohio State University, Columbus 43210 \\ ${ }^{3}$ The Institute of Rural Sciences, University of Wales Aberystwyth, Llanbadarn Fawr, Aberystwyth, UK
}

\begin{abstract}
We have recently developed a real-time polymerase chain reaction (PCR) assay to quantify copies of the genes encoding protozoal 18S rRNA. The assay includes procedures for isolating and concentrating protozoal cells from the rumen for use as a standard to convert 18S rRNA gene copies to a biomass basis. The current objectives were to 1 ) determine the degree of reduction of bacterial contamination in the protozoal standard, 2) determine if protozoal standards derived from ruminal fluid are appropriate for predicting duodenal flows, and 3) evaluate the assay's determined values for protozoal $\mathrm{N}$ in the rumen and flowing to the duodenum compared with independent measurements. Our protozoal collection method reduced nonassociated bacterial contamination by 33 -fold, the contamination of which could otherwise significantly bias RNA (microbial marker) and N percentages of concentrated protozoal fractions. Based on denaturing gradient gel electrophoresis, the use of protozoal cells isolated from ruminal fluid appears appropriate for use in quantitative assays determining protozoal $\mathrm{N}$ flow postruminally. Using real-time PCR, protozoal N was determined to be 4.8 and $12.7 \%$ of the rumen microbial $\mathrm{N}$ pool and 5.9 and $11.9 \%$ of the duodenal flow of microbial $\mathrm{N}$ on diets containing low (16\%) or high (21\%) forage neutral detergent fiber, respectively, which were comparable with independent measures and expectations.
\end{abstract}

(Key words: rumen protozoal nitrogen, real-time PCR, denaturing gradient gel electrophoresis, rRNA)

Abbreviation key: DGGE = denaturing gradient gel electrophoresis, DNDF = potentially digestible NDF,

Received November 2, 2004.

Accepted February 23, 2005.

Corresponding author: J. L. Firkins; e-mail: firkins.1@osu.edu.

* Research was supported by state and federal funds appropriated to the Ohio Agricultural and Development Center, The Ohio State University (manuscript number 25-04AS) and from USDA/NRICGP Grant 2003-35206-12872.
$\mathbf{H F}=$ high forage diet, $\mathbf{L F}=$ low forage diet, $\mathbf{r D N A}=$ gene encoding ribosomal RNA.

\section{INTRODUCTION}

Microbial CP is the most important source of metabolizable protein for ruminant animals because of its quantity and excellent amino acid profile (NRC, 2001). Systems such as the NRC (2001) use actual flow data to either derive or evaluate the predicted supply of metabolizable protein. One of the most important factors influencing microbial protein supply to the dairy cow and its resultant prediction is related to incompletely understood protozoal metabolism (Dijkstra et al., 1998; Firkins et al., 1998), particularly their extensive predation of bacteria and their high recycling rates within the rumen. The predictability of future metabolizable protein systems would be improved by a means to more accurately measure protozoal flow, and thus total microbial $\mathrm{N}$ flow, to the duodenum. Moreover, more accurate data for duodenal flow of protozoal $\mathrm{N}$ relative to ruminal pool size of protozoal $\mathrm{N}$ would allow for a better mechanistic assessment of the ramifications of protozoal ecology on efficiency of microbial protein synthesis in the rumen and therefore greater efficiency of dietary $\mathrm{N}$ usage (Firkins and Reynolds, 2005).

Despite the importance and need for more research quantifying rumen pool size and duodenal flow of protozoal N, research in this area is hindered by the lack of an accurate protozoal marker (Firkins et al., 1998). Although protozoal $\mathrm{N}$ flow to the duodenum has been approximated to be about one-half that of the rumen pool (Jouany, 1996), comprising 20 to $40 \%$ of the total microbial $\mathrm{N}$ in the duodenum, most digesta flow studies ignore protozoal marker: $\mathrm{N}$ ratios, which can significantly decrease accuracy (Broderick and Merchen, 1992). Intentional ignoring of protozoa has been inappropriately justified based on results using indirect procedures, the combination of which appears to compound to underestimate duodenal flow of protozoal N (Firkins et al., 1987a). In contrast, indirect methods not relying on these potentially biased procedures tend 
to provide generally higher protozoal $\mathrm{N}$ flows (Steinhour et al., 1982; Shabi et al., 2000).

To assess effects of protozoal ecology on ruminal $\mathrm{N}$ metabolism, many researchers have counted total protozoa or have divided them into isotrichids and entodiniomorphids by their cilia pattern. However, protozoa vary considerably in biomass per cell (Williams and Coleman, 1992), so counts should be converted to a biomass basis for nutritional purposes. Although protozoal cells lyse in the abomasum, direct quantification of omasal flow of protozoal cells and $\mathrm{N}$ can be done (Ahvenjärvi et al., 2002), but these workers noted potentially significant underestimation of protozoal $\mathrm{N}$ because of potential efflux of very small protozoa through the pores of their filters. Besides capturing protozoa for direct quantification purposes, filtration has been used to provide a more representative sample of protozoa to be used for marker studies (Martin et al., 1994). Classical approaches used in many published reports used gravitational separation of protozoal cells from flocculating ruminal fluid primarily using separatory funnels (Firkins et al., 1987a; Shabi et al., 2000) or centrifugation (Punia and Leibholz, 1994; Ivan et al., 2000). These procedures could have significant amounts of contamination of bacterial matter (Sharp et al., 1998; Volden et al., 1999; Sylvester et al., 2004), so the accuracy of a direct protozoal marker could be decreased by the procedures used to harvest a reference protozoal fraction. This reference should accurately represent the protozoal populations in the rumen pool while minimizing contamination by plant matter and bacteria. Finally, even a more highly purified protozoal sample collected from the rumen might not represent the protozoa flowing to the duodenum because of possible selective retention of certain genera (Leng and Nolan, 1984; Dehority, 2003) and potentially different marker: $\mathrm{N}$ ratios among those populations.

Sylvester et al. (2004) recently developed an assay to measure protozoal biomass in ruminal and duodenal digesta by targeting and quantifying the DNA encoding 18S rRNA (rDNA). The assay includes a procedure with steps to concentrate protozoal cells by filtration while reducing contamination of nonassociated bacteria (i.e., bacteria not attached externally to or living inside protozoa). In experiment 1 , our objective was to determine the degree of reduction of bacterial contamination in the protozoal standard derived by filtration compared with a traditional sedimentation procedure. In experiment 2 , our objectives were to determine if protozoal standards representing predominant protozoal genera in ruminal fluid are appropriate for predicting protozoal $\mathrm{N}$ flows to the duodenum and to evaluate data obtained from our real-time PCR assay pre- dicting protozoal $\mathrm{N}$ pool size in the rumen and flowing to the duodenum in lactating cows fed typical dairy diets compared with measurements from independent procedures.

\section{MATERIALS AND METHODS}

\section{Experiment 1}

Ruminal fluid (about $800 \mathrm{~mL}$ ) was collected and protozoa harvested as described by Sylvester et al. (2004) from approximately $2.5 \mathrm{~kg}$ of ruminal digesta taken from 10 different locations within the rumens of 3 rumen-cannulated Holstein cows at 2 and $5 \mathrm{~h}$ after feeding a TMR containing $46 \%$ forage, $40 \%$ concentrate, and $14 \%$ cottonseed. The ruminal fluid was diluted with an equal volume of Coleman buffer (Williams and Coleman, 1992), placed in a $39^{\circ} \mathrm{C}$ water bath, and allowed to flocculate for $45 \mathrm{~min}$. The flocculent layer was aspirated, and the remaining clarified ruminal fluid was treated with formalin (1\% final concentration, wt/vol).

The samples were mixed and separated into equal volumes. Each volume was randomly assigned to either the sedimentation technique (Punia and Leibholz, 1994) or a revised filtration procedure described by Sylvester et al. (2004). Protozoa-rich fractions (2- and 5 -h samples) were composited by cow and suspended in $30 \mathrm{~mL}$ of $0.9 \%$ saline. Subsamples $(10 \mathrm{~mL})$ of each protozoal sample were stored at $4^{\circ} \mathrm{C}$ for bacterial and protozoal enumeration, and the remaining $20 \mathrm{~mL}$ was lyophilized for N and RNA determination. Protozoalfree fluid from each protozoal harvesting method was retained and pooled; bacteria were collected by centrifuging at $14,000 \times g$ for $25 \mathrm{~min}$ and were split into 2 equal and representative volumes. One half was lyophilized for subsequent chemical analyses, and the other half was stored at $4^{\circ} \mathrm{C}$ for bacterial enumeration.

Protozoal cell enumeration was done using the method outlined by Dehority (1993). Bacterial cell enumeration was done using epifluorescence microscopy on an Olympus BX 21 upright epifluorescent microscope (Melville, NY). To quantify bacterial contamination of harvested protozoa samples, we assumed that 1) bacteria that are associated with protozoa should be considered as an integral part of the protozoal fraction, and 2) dilutions used to count the bacteria consisted of nonadherent bacterial cells only (i.e., all protozoal cells and their associated bacteria were diluted to extinction). Protozoal cell samples harvested from each protozoal collection method were serially diluted, and the numbers of bacterial cells contaminating them were counted using the method described by $\mathrm{Yu}$ et al. (1995), with slight modifications. Briefly, samples were incubated overnight with Triton X-100 (0.1\%, 
final concentration) to unclump bacterial cells that were stained with $4^{\prime}, 6$-diamidino-2-phenylindole, and quantitatively passed through a $0.2-\mu \mathrm{m}$ polycarbonate filter. Filters were air-dried and mounted on slides, coverslips were mounted using nail polish at each corner, and slides were stored in the dark until enumeration was completed. Additional modifications included: 1) no addition of $\mathrm{NaCl}$ or $\mathrm{Na}_{4} \mathrm{P}_{2} \mathrm{O}_{7}$ because protozoal suspension includes $\mathrm{NaCl}$, and 2) bacterial cells present within 40 random grids were counted instead of 8 to 20 grids. Bacterial cells were determined randomly from each sample using 2 replicate dilution series and 2 duplicate filter counts completed on $2 \mathrm{~d}$.

\section{Experiment 2}

Feeding conditions. Two multiparous Holstein cows (identified as 647 and 660), which were fitted with rumen and simple $\mathrm{T}$ duodenal cannulas anterior to the pancreatic duct, were used in a randomized complete block design to which the cows were considered the blocking criterion (Sylvester et al., 2004). Cows averaged $773 \mathrm{~kg}$ of BW, $24.5 \mathrm{~kg} / \mathrm{d}$ DMI, and 35.1 $\mathrm{kg} / \mathrm{d}$ of milk during the experiment. Cows were fed 1 of 2 control diets containing either 21 or $16 \%$ forage NDF [high forage (HF) and low forage (LF) respectively], which were part of a larger study (Lima et al., 2003). Diets were prepared once daily as a TMR, and animals were fed diets at $110 \%$ of ad libitum at 0600 and $1800 \mathrm{~h}$ for 14-d periods. Daily samples of feed offered and refused were composited by cow within sample type and dried at $55^{\circ} \mathrm{C}$. Pellets containing $5 \%$ $\mathrm{Cr}_{2} \mathrm{O}_{3}$ and $95 \%$ soybean hulls were dosed into the rumen twice daily through the ruminal cannula at $1.1 \%$ of the diet DM starting on $\mathrm{d} 5$ for use as a digesta flow marker as described previously (Harvatine et al., 2002a). Pellets were subsampled weekly, dried at $55^{\circ} \mathrm{C}$, and composited by period.

Digesta sampling. Ruminal fluid was collected (approximately $1000 \mathrm{~mL}$ ), as described previously, on d 8 through 11 of each period at $0700,0900,1200,1500$, and $1700 \mathrm{~h}$, and then pooled to represent a 24 -h feeding cycle. Subsamples $(50 \mathrm{~mL})$ from each time point were treated with formalin ( $1 \% \mathrm{wt} / \mathrm{vol}$ final concentration) and pooled for use in DNA extraction, and the remaining $950 \mathrm{~mL}$ was used for protozoal harvesting. Protozoal collection, enumeration, and generic identification were completed as described for experiment 1 .

A 200-mL solution of CoEDTA (Uden et al., 1980) was pulse dosed via the rumen cannula on $d 11$ of each period and mixed thoroughly. Ruminal fluid was collected (1000 mL) as described previously at 0,20 , and $40 \mathrm{~min}$ and at 1, 2, 4, 6, 9, 12, 18, 24, and $36 \mathrm{~h}$ postdosing; 50-mL aliquots were taken and frozen at $-20^{\circ} \mathrm{C}$ for CoEDTA determination, and the remainder was returned to the rumen.

Duodenal samples $(250 \mathrm{~mL})$ were taken on d 9 to 12 of each period so that every 90 -min interval in a $24-\mathrm{h}$ period were represented (16 samples total), combined by cow within period, and frozen immediately for subsequent analyses.

Total ruminal digesta were quantitatively evacuated as previously described by Harvatine et al. (2002b) by fractionating the fluids from the solids at $0400 \mathrm{~h} \mathrm{(d} \mathrm{13)}$ and $0800 \mathrm{~h} \mathrm{(d} \mathrm{14)} \mathrm{of} \mathrm{each} \mathrm{period,} \mathrm{before}$ weighing, subsampling, and reconstitution. After the last evacuation, half of the respective cow's ruminal content was mixed with half of the content from the cow on the dietary treatment to which that cow was being switched. Cows were immediately fed their new diets after return of the ruminal contents. An extra week of adaptation was provided for the first period. Although the adjustment period for the remainder of periods was only $8 \mathrm{~d}$ (the last day of the previous period plus $7 \mathrm{~d}$ of the subsequent period), we assumed that this mixing of ruminal contents would allow a fast enough adaptation of microbial populations between sampling periods. Bacteria (Klieve et al., 2003) and protozoa (Soliva et al., 2004) stabilized after about 1 wk of adaptation to a change in dietary conditions that was much harsher than ours was. Logistical limitations prevented us from having longer adaptation periods. Subsamples of evacuated ruminal contents were reconstituted and stored at $-20^{\circ} \mathrm{C}$ for ruminal pool size measurements as described subsequently. In addition, approximately $2 \mathrm{~kg}$ of these samples was used for harvesting particle-associated bacteria by blending (Callison et al., 2001), and the remaining $2 \mathrm{~kg}$ was dried at $55^{\circ} \mathrm{C}$ to estimate ruminal $\mathrm{DM}$ pool size $\left(55^{\circ} \mathrm{C} \mathrm{DM} \times\right.$ total rumen wet weight) and ruminal fluid volume (total weight - DM pool size).

Laboratory analyses. All dried and lyophilized digesta samples were ground to pass through a $2-\mathrm{mm}$ screen using a Wiley mill (Arthur H. Thomas, Philadelphia, PA). Lyophilized bacteria and protozoal cells were ground using a mortar and pestle. All samples were analyzed for DM and OM according to AOAC (1990). Chromic oxide pellets and duodenal samples were analyzed for $\mathrm{Cr}$ by atomic absorption spectroscopy (Williams et al., 1962). Rumen, duodenal, protozoal, and bacterial samples were analyzed for Kjeldahl $\mathrm{N}$ and total purines (Zinn and Owens, 1986) as modified by Ushida et al. (1985), with standardization to a total RNA basis. Indigestible NDF (10-d in vitro), potentially digestible NDF (DNDF), and Co were determined as described previously (Harvatine et al., 2002b). 
Table 1. Oligonucleotide primer sets used to amplify DNA extracted from rumen and duodenal digesta samples in experiment 2.

\begin{tabular}{|c|c|c|}
\hline Primer & Sequence, $5^{\prime}$ to $3^{\prime}$ & $\begin{array}{l}\text { Expected } \\
\text { amplicon } \\
\text { length }\end{array}$ \\
\hline \multicolumn{3}{|l|}{ Set $1^{1}$} \\
\hline P-SSU-1617-r-GC ${ }^{2}$ & $\frac{\text { CGC CCG CCG CGC CCC GCG CCC GGC CCG CCC CCG CCC GGG GCC }}{\text { AAT TGC AAA GAT CTA TCCC }}$ & 297 \\
\hline Set $2^{3}$ & & \\
\hline
\end{tabular}

${ }^{1}$ Primer set 1 from Regensbogenova et al. (2004).

${ }^{2} \mathrm{GC}$ designates that primer contains a clamp (underlined).

${ }^{3}$ Primer set 2 from Sylvester et al. (2004).

Real-time PCR assay for protozoal $N$ and electrophoresis analyses. Ruminal fluid, duodenal digesta, and harvested protozoal cells were analyzed to determine the protozoal rDNA concentration using a real-time PCR assay developed by Sylvester et al. (2004). Briefly, total genomic DNA was extracted from triplicate 0.5-mL ruminal and duodenal digesta samples and from approximately 1 million protozoal cells harvested and purified from ruminal fluid and counted by microscopy. The extracted DNA of each respective sample was amplified using PCR to generate the corresponding standards and individual standard curves for each sample for the real-time PCR assay, which included correction factors for recovery of genomic DNA during extraction from the samples.

From the same triplicate DNA extractions, $25 \mu \mathrm{L}$ of genomic DNA per sample was composited for use in denaturing gradient gel electrophoresis (DGGE) to compare banding profiles of the protozoal rDNA from the rumen vs. duodenum. Two independent ciliatespecific PCR primer sets (Table 1) were used to amplify 2 separate regions near the $5^{\prime}$ and $3^{\prime}$ ends of the $18 \mathrm{~S}$ rDNA. Amplification conditions and primer set 1 (1320f and 1617r) are from Regensbogenova et al. (2004) as follows: One cycle of $94^{\circ} \mathrm{C}$ for $4 \mathrm{~min}$, annealing at $60^{\circ} \mathrm{C}$ for $30 \mathrm{~s}$, and extension at $72^{\circ} \mathrm{C}$ for $1 \mathrm{~min}$; 35 cycles of $94^{\circ} \mathrm{C}$ for $1 \mathrm{~min}$, annealing at $60^{\circ} \mathrm{C}$ for 30 $\mathrm{s}$, and extension at $72^{\circ} \mathrm{C}$ for $1 \mathrm{~min}$; and one cycle of $94^{\circ} \mathrm{C}$ for $4 \mathrm{~min}, 60^{\circ} \mathrm{C}$ for $30 \mathrm{~s}$, and $72^{\circ} \mathrm{C}$ for $10 \mathrm{~min}$. Amplification conditions for primer set 2 (316f and $539 \mathrm{r}$ ) are the same except that annealing temperature was lowered to $56^{\circ} \mathrm{C}$. Primer set 2 was previously designed and verified for real-time PCR quantification of protozoal rDNA (Sylvester et al., 2004). The reverse primer (539r) was modified for DGGE analysis by adding a GC clamp (Table 1). Reaction volumes for both primer sets were $100 \mu \mathrm{L}$ containing $100 \mathrm{pmol}$ of each primer, $125 \mu M$ of each dNTP mixture, $2 \mathrm{mM}$ magnesium chloride, $0.05 \%$ BSA, $1 \times$ PCR buffer, and $5.0 \mathrm{U}$ of platinum Taq DNA polymerase (Invitrogen, Carlsbad, CA). Amplicons were electrophoresed on 1\% agarose gel and visualized after staining with ethidium bromide. When multiple bands were observed using primer set 1 (1320f-1617r), bands of expected molecular size were excised and gel-purified before use in DGGE analysis.

Denaturing gradient gel electrophoresis was performed using the Dcode Universal Mutation Detection system (16-cm system, BioRad, Hercules, CA) with 20 $\mu \mathrm{L}$ of PCR products from all samples. Gel concentrations and denaturing gradients were optimized for amplicons produced from each primer set. Amplicons generated from primer set 1 were electrophoresed using $6 \% \mathrm{wt} / \mathrm{vol}$ gel (acrylamide: bisacrylamide 37.5:1) with a denaturing gradient ranging from 20 to $35 \%$ of urea and formamide (100\% corresponds to $7 M$ urea and $40 \% \mathrm{wt} / \mathrm{vol}$ formamide) increasing in the direction of the electrophoresis run. The electrophoresis was performed at a constant $130 \mathrm{~V}$ for $3.5 \mathrm{~h}$ and a constant temperature of $60^{\circ} \mathrm{C}$. Electrophoresis of amplicons generated by primer set 2 was completed using $8 \%$ wt/vol gel (acrylamide: bisacrylamide 37.5:1) with a denaturing gradient from 28 to $43 \%$ of urea and formamide. The electrophoresis was performed at a constant $80 \mathrm{~V}$ for $18 \mathrm{~h}$ and a constant $60^{\circ} \mathrm{C}$. After the run, gels were stained for $30 \mathrm{~min}$ in $0.5 \times$ Tris-borate-EDTA buffer containing GelStar nucleic acid stain (BioWhittaker, Inc., Walkersville, MD), and banding patterns were documented using a FluorChem Imaging System (Alpha Innotech Corp., San Leandro, CA).

Resulting bands were isolated from gels using a sterile pipette tip and transferred to sterile $0.5-\mathrm{mL}$ tubes containing $30 \mu \mathrm{L}$ of Tris-EDTA buffer. Tubes were subjected to 3 cycles of freezing at $-80^{\circ} \mathrm{C}$ for $10 \mathrm{~min}$ followed by thawing in a water bath at $55^{\circ} \mathrm{C}$ for 15 min to allow diffusion of the amplicons. Amplicons were reamplified using primers and conditions previously described, purified, and sent for sequencing. 
The DNA sequences were checked for errors by manual evaluation of their respective electrophoretograms. Sequences were identified by comparing to GenBank (Benson et al., 2004) sequencing with the BLAST program (Altscul et al., 1990), and the highest identity to a known sequence was reported.

Calculations. Protozoal standards of known volumes and concentrations of protozoal cells were lyophilized. After the mass of the dried residue was recorded, the concentrations of $\mathrm{N}$, RNA, or rDNA copies could be quantitatively reconstituted to a cell number basis. The total ruminal pool of protozoal cell numbers was determined by multiplying cell concentrations $\times$ ruminal fluid volume, which was determined by rumen evacuation. This pool was multiplied by the concentrations of N, RNA, or rDNA copies per cell (using protozoal standards) to determine their respective ruminal pool sizes. Hereafter, these calculations will be referred to as the gravimetric method for independent comparison of results obtained using the real-time PCR assay. Ruminal pool size of protozoal $\mathrm{N}$ was calculated using the following 2 equations:

$$
\begin{gathered}
\text { Real-time PCR procedure: Rumen DM pool }(\mathrm{g}) \\
\times \text { protozoal rDNA copies/g of DM } \\
\text { of the rumen sample } \times \mathrm{g} \text { of } \mathrm{N} / \mathrm{rDNA} \\
\text { copies in the protozoal standard }
\end{gathered}
$$

Gravimetric procedure: Rumen volume (mL)

$\times$ protozoal cells $/ \mathrm{mL}$ of rumen sample

$\times \mathrm{N}$ :protozoal cell in protozoal standard (g/cell)

The ruminal pools of bacterial $\mathrm{N}$ were determined using the following 2 equations:
Real-time PCR procedure: \{Rumen DM pool (g)
$\times$ purines in rumen sample $(\mathrm{g} / \mathrm{g}$ of $\mathrm{DM})$
- [1] $\times$ purine: $\mathrm{N}$ in protozoal standard $(\mathrm{g} / \mathrm{g})\}$ $\times \mathrm{N}$ :purines of bacteria $(\mathrm{g} / \mathrm{g})$

Gravimetric procedure: \{Rumen DM pool (g)

$\times$ purines in rumen sample $(\mathrm{g} / \mathrm{g}$ of $\mathrm{DM})$

$-[2] \times$ purine: $\mathrm{N}$ in protozoal standard $(\mathrm{g} / \mathrm{g})\}$ $\times \mathrm{N}$ :purines of bacteria $(\mathrm{g} / \mathrm{g})$

The average amount of $\mathrm{Cr}$ dosed daily was divided by the concentration of $\mathrm{Cr}$ in the duodenal samples to determine daily flow of DM to the duodenum. Ruminal fluid dilution rate was determined by nonlinear regression of CoEDTA dilution, and passage rate of DNDF was calculated as described previously (Harvatine et al., 2002b). These fractional rates were multiplied $x$ $24 \mathrm{~h} / \mathrm{d}$ to convert to a daily basis. Protozoal N flow to the duodenum (g/d) was determined using the following 3 equations:

Real-time PCR procedure: Duodenal flow of DM $(\mathrm{g} / \mathrm{d}) \times$ protozoal $\mathrm{rDNA}$ copies/g of DM of duodenal sample $\times \mathrm{g}$ of N:rDNA copies in protozoal standard

Gravimetric procedure: Ruminal fluid dilution rate $\left(\mathrm{d}^{-1}\right) \times[2]$
Gravimetric procedure: Ruminal DNDF passage rate $\left(d^{-1}\right) \times[2]$

Bacterial $\mathrm{N}$ flow to the duodenum was calculated using the following equation:

$$
\begin{aligned}
& \text { Real-time PCR procedure: }\{\text { Duodenal DM flow } \\
& (\mathrm{g} / \mathrm{d}) \times \text { purines in duodenal sample } \\
& (\mathrm{g} / \mathrm{g} \text { of } \mathrm{DM})-[5] \times \text { purine:N in protozoal } \\
& \text { standard }(\mathrm{g} / \mathrm{g})\} \times \mathrm{N} \text { :purines in bacteria }(\mathrm{g} / \mathrm{g})
\end{aligned}
$$

\section{Statistical Analyses}

Experiment 1. Data were analyzed using Proc MIXED of SAS (SAS Institute, 1999) according to the following model:

$$
\mathrm{Y}_{\mathrm{ijk}}=\mu+\mathrm{M}_{\mathrm{i}}+\mathrm{C}_{\mathrm{j}}+\mathrm{D}_{\mathrm{k}}+\mathrm{M}_{\mathrm{i}} \times \mathrm{C}_{\mathrm{j}}+\mathrm{e}_{\mathrm{ijk}}
$$

where $Y_{i j}$ is the dependent, continuous variable; $\mu$ is the overall population mean; $M_{i}$ is the fixed effect of the ith method ( $\mathrm{i}=$ sedimentation or filtration); $\mathrm{C}$ is the fixed effect of the jth cow $(\mathrm{j}=1,2,3)$; $\mathrm{D}$ is the fixed effect of the kth day ( $\mathrm{k}=1$ or 2$) ; \mathrm{M}_{\mathrm{i}} \times \mathrm{C}_{\mathrm{j}}$ is the interaction between the ith method and the jth cow; and $\mathrm{e}_{\mathrm{ij}}$ is the residual error, assumed independent and $\mathrm{N}\left(0, \sigma_{\mathrm{e}}^{2}\right)$.

Experiment 2. Data were analyzed using Proc MIXED of SAS (SAS Institute, 1999) according to the following model:

$$
\mathrm{Y}_{\mathrm{ijk}}=\mu+\mathrm{T}_{\mathrm{i}}+\mathrm{C}_{\mathrm{j}}+\mathrm{M}_{\mathrm{k}}+\mathrm{e}_{\mathrm{ijk}}
$$

where $\mathrm{Y}_{\mathrm{ijk}}$ is the dependent, continuous variable; $\mu$ is the overall population mean; $T_{i}$ is the fixed effect of the ith dietary treatment ( $\mathrm{i}=\mathrm{HF}$ or $\mathrm{LF})$; $\mathrm{C}$ is the fixed effect of the jth cow ( $\mathrm{j}=1$ or 2$) ; \mathrm{M}_{\mathrm{k}}$ is the fixed effect of the kth method ( $k=$ PCR or gravimetric); and $e_{i j k}$ is the residual error, assumed independent. Variance homogeneity between different methods (i.e., $\mathrm{N}\left(0, \sigma_{\mathrm{e}}^{2}\right)$ ) was tested using the COVTEST option, with method repeated within cow across treatments and 
Table 2. Contamination of bacterial biomass in concentrated protozoal samples harvested by 2 methods (sedimentation and filtration) in experiment 1.

\begin{tabular}{lcll}
\hline Item & Sedimentation & Filtration & Bacterial $^{\text {cells }^{1}}$ \\
\hline $\mathrm{DM}, \%$ & 4.56 & 8.08 & 2.69 \\
$\mathrm{~N}, \%$ of DM & 3.82 & 6.95 & 6.00 \\
$\mathrm{RNA} \%$ of DM & 4.46 & 6.12 & 8.80 \\
Bacterial N, \% of microbial N & 47.5 & 2.66 & $\ldots$ \\
Bacterial RNA, \% of microbial RNA & 30.2 & 4.37 & $\ldots$ \\
\hline
\end{tabular}

\footnotetext{
${ }^{1}$ Bacterial cells were recovered during the harvesting of protozoa and pooled from 3 cows. This fraction had $55.3 \times 10^{9}$ cells $/ \mathrm{mL}$.

${ }^{2}$ Bacterial N ( $2.99 \mathrm{mg} / 10^{9}$ bacterial cells) was determined from the bacterial cell fraction $[6.0 \% \mathrm{~N} \times(0.028$ $\mathrm{g}$ of DM $/ \mathrm{mL}) /\left(55.3 \times 10^{9}\right.$ cells $\left.\left./ \mathrm{mL}\right)\right]$ and multiplied by the bacterial cell numbers in the respective protozoal fractions (see Figure 1). Protozoal N $\left(0.546 \mathrm{mg} / 10^{6}\right.$ cells) was determined from protozoa harvested by filtration $\left[6.95 \% \mathrm{~N} \times(0.088 \mathrm{~g}\right.$ of $\mathrm{DM} / \mathrm{mL}) /\left(11.2 \times 10^{6}\right.$ protozoal cell $\left.\left.\mathrm{s} / \mathrm{mL}\right)\right]$ and multiplied by the protozoal cell numbers in the respective protozoal fractions. For example, $2.99 \mathrm{mg}$ of N/10 $10^{9}$ bacterial cells $\times 37.0 \times 10^{9}$ cells $/ \mathrm{mL}=$ $1.11 \mathrm{mg}$ of bacterial N/mL; $0.546 \mathrm{mg}$ of N/10 $0^{6}$ protozoal cells $\times 2.25 \times 10^{6}$ cells $=1.23 \mathrm{mg}$ of protozoal N/ $\mathrm{mL} ; 1.11 /(1.11+1.23)=47.5 \%$ bacterial $\mathrm{N}$ contamination in the sedimented sample.

${ }^{3}$ Bacterial RNA contamination was determined as for $\mathrm{N}$ contamination.
}

significance declared at $P>0.2$. When variances between methods were deemed homogeneous, the repeated statement was removed, and SEM were pooled. Treatment means were separated using Fisher's $F$ test-protected LSD, and significance was declared at $P<0.05$ unless otherwise stated.

\section{RESULTS AND DISCUSSION}

\section{Experiment 1}

Although some researchers used separatory funnels (Firkins et al., 1987a; Shabi et al., 2000) or similar techniques to separate sedimented protozoa, we chose to centrifuge at slow speed (Punia and Leibholz, 1994; Ivan et al., 2000) to reduce user subjectivity. Moreover, in our preliminary studies, sedimented protozoa that were aspirated with a Pasteur pipette from the bottom of an Erlenmeyer flask were biased toward isotrichid protozoa, particularly if the sample was taken shortly after feeding the cow (data not shown). Based on the lower N and RNA concentrations (Table 2), the sedimented protozoal sample appears to contain much more contamination with plant material than does the filtered protozoal sample. Such contamination might explain the relatively variable N:RNA ratios of protozoal preparations compared with bacterial samples (Firkins et al., 1987a; Volden et al., 1999).

Bacterial counts in the protozoal sample prepared using the filtration method were decreased $(P<0.05)$ to only $15 \%$ of those in the sedimented sample (5.58 vs. $37.1 \times 10^{9} / \mathrm{mL}$ ), whereas the protozoal cells were 5 fold more $(P<0.05)$ concentrated $\left(11.2\right.$ vs. $2.25 \times 10^{6} /$ $\mathrm{mL}$ ) in the filter method (Figure 1). The net result is a 33 -fold reduction in bacterial contamination using our filtration procedure.
The significant plant contamination in sedimented protozoa would have biased our objectives to determine the degree to which bacterial N and RNA contamination affects true $\mathrm{N}$ and RNA concentrations of protozoa. The distribution of protozoal genera was similar in the sedimented compared with filtered protozoa (data not shown) and therefore should have similar RNA:N. Thus, using calculations of RNA or N per cell of the filtration-harvested protozoa to correct the calculations for sedimented protozoa should reduce error from plant contamination while introducing little bias in the comparison of sedimented vs. filtration bacterial $\mathrm{N}$ and RNA contamination. We determined RNA and $\mathrm{N}$ in bacteria harvested from both of the protozoal separation procedures, converted these concentrations to a per bacterial cell basis, and then derived the mean concentration from both protozoal harvesting procedures to estimate bacterial $\mathrm{N}$ and RNA per contaminating bacterial cell (i.e., bacteria not associated with protozoa).

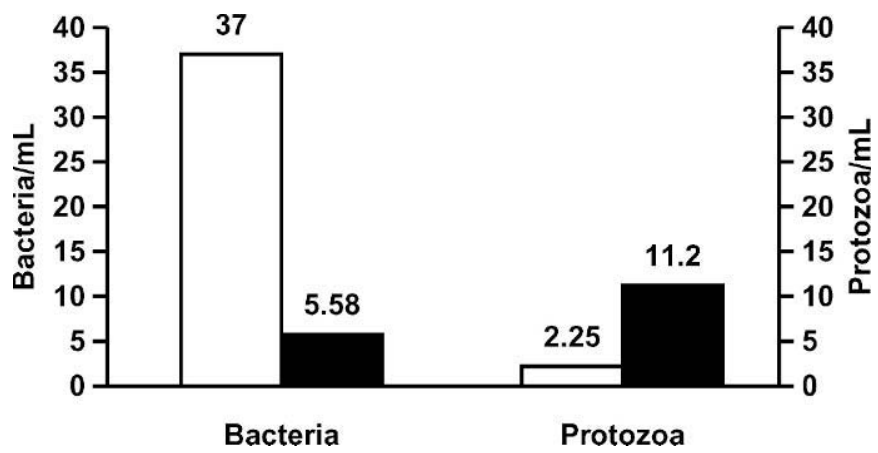

Figure 1. Bacterial $\left(\times 10^{9}\right)$ and protozoal $\left(\times 10^{6}\right)$ cell counts in protozoal samples harvested by sedimentation (open bars) or filtration (filled bars). 
Using calculations described in the footnotes of Table 2 , the 47.5 and $60.2 \%$ contribution of bacterial $\mathrm{N}$ and RNA in sedimented protozoal samples provides clear evidence that previous data using this or similar protozoal harvesting techniques could be profoundly in error. The higher values than the roughly $20 \%$ of total small subunit rRNA of bacterial origin (Sharp et al., 1998) reflect differences in the ratios of N:rRNA in bacteria vs. protozoa. Our values are also higher than in other studies because the current calculation is represented as a percentage of total microbial N, rather than as a percentage of total $\mathrm{N}$ (which includes other sources besides bacteria and protozoa), but also because we used the more pure filtration-derived protozoa containing higher $\mathrm{N}$ and RNA concentrations in the protozoal biomass. Although Martin et al. (1994) did not find detectable diaminopimelic acid in their filtered protozoal samples using the original filtration procedure, Volden et al. (1999) estimated bacterial N (again using diaminopimelic acid) to be up to 23\% of the total $\mathrm{N}$ in the protozoal sample. Microscopic evaluations of the successive washes (data not shown) confirmed that our serial dialysis washing procedure (Sylvester et al., 2004) markedly reduced the contamination of bacteria not associated with protozoa compared with the original filtration method (Martin et al., 1994).

\section{Experiment 2}

Our objectives were to provide quantitative, independent measurements to evaluate our protozoal realtime PCR assay (Sylvester et al., 2004). Numerous samples were collected and analyzed for validation of various steps (data not shown), thus restricting our ability to sample only 2 dairy cattle fed different diets. A more complete analysis of microbial differences between those 2 diets would clearly take more animals but would also require more streamlined, routine procedures to measure protozoal $\mathrm{N}$ than could be accomplished in the current study. Statistical analyses were performed with the primary objective to prove homogeneity of variance for the intention of providing reasonable assessments of variation for future researchers, who would need a valid assessment of experimental variation with which to estimate number of animal replications needed to provide suitable statistical power (Berndtson, 1991).

The $\mathrm{N}$ and RNA concentrations of protozoa collected using the current protozoal filtration method and bacteria harvested directly from the ruminal fluid (i.e., not obtained from the protozoal filtrate as in experiment 1) are shown in Table 3 . The high $\mathrm{N}$ and RNA concentrations in the protozoal samples indicate successful re-
Table 3. Mean composition of protozoa and bacteria standards used in microbial $\mathrm{N}$ calculations ${ }^{1}$ for 2 cows fed diets differing in forage $\mathrm{NDF}^{2}$ in experiment 2.

\begin{tabular}{llllll}
\hline & \multicolumn{2}{c}{ LF } & & \multicolumn{2}{c}{ HF } \\
\cline { 2 - 3 } \cline { 6 - 6 } \cline { 5 - 6 } & Protozoa & Bacteria & & Protozoa & Bacteria \\
\hline DM, \% & 7.88 & 3.49 & & 10.1 & 1.94 \\
N, \% of DM & 7.50 & 4.94 & & 8.05 & 5.40 \\
RNA, \% of DM & 7.92 & 5.77 & & 7.72 & 6.20 \\
\hline
\end{tabular}

${ }^{1}$ Protozoa were harvested using the modified filtration procedure (Sylvester et al., 2004), and bacteria were harvested by blending and differential centrifugation (Callison et al., 2001); $\mathrm{n}=3$.

${ }^{2} \mathrm{LF}=$ Low forage: $16 \%$ forage NDF; HF = high forage: $21 \%$ forage $\mathrm{NDF}$.

moval of contaminating plant material (which has lower $\mathrm{N}$ and RNA concentrations). The slightly lower values for bacterial $\mathrm{N}$ than those seen in some reports (Clark et al., 1992) probably are a result of salt contamination from saline in our final wash (other studies used distilled water) or from greater deposition of stored carbohydrate from these relatively high-grain diets. Although our blending procedure could cause more plant contamination, which could decrease $\mathrm{N}$, we note that several researchers in the Clark et al. (1992) database blended samples to detach bacteria.

The protozoal $\mathrm{N}$ pool size in the rumen was lower ( $P=0.01$ and 0.05 for the real-time PCR and gravimetric procedures, respectively) for cows fed LF than for those fed the HF diet (Table 4). For cows fed HF, pool sizes were nearly identical (27.4 and $28.1 \mathrm{~g}$ ) for the real-time PCR and gravimetric procedures. In contrast, for cows fed LF, protozoal N pool sizes were lower for the real-time PCR method than the gravimetric method. This apparent discrepancy might be due to a discrepancy in rDNA copies per protozoan cell (see later discussion). Variances were not different $(P>0.2)$ between the 2 methods, suggesting that each method estimated means with the same precision.

Although references are often cited supporting the contention that protozoal $\mathrm{N}$ can exceed $50 \%$ of the total microbial $\mathrm{N}$ in the rumen (Coleman, 1979; Jouany, 1996), these data are from animals fed much differently than ours (e.g., low DMI or with high sugar diets) and often with procedures with dubious accuracy. The relatively lower percentages reported in our study ( 4.8 and $12.7 \%$ protozoal in microbial $\mathrm{N}$ for LF and HF, respectively) are more congruent with results using a similar approach of quantifying protozoal $\mathrm{N}$ outflow to the omasum (omasal fluid flow $\times$ omasal protozoal counts $\times \mathrm{N} /$ cell ratio) and correction of total ${ }^{15} \mathrm{~N}$ for protozoal ${ }^{15} \mathrm{~N}$, with the bacterial (by difference) flow of ${ }^{15} \mathrm{~N}$ used to quantify bacterial $\mathrm{N}$ (Ahvenjärvi et al., 2002). In that study, protozoal $\mathrm{N}$ varied from 4.3 to $10.4 \%$ of total microbial N, although the authors com- 
Table 4. Ruminal pool size and duodenal flow measurements of microbial $\mathrm{N}$ determined using real-time PCR or the gravimetric procedures for cows fed diets differing in forage $\mathrm{NDF}^{1}$ in experiment 2 .

\begin{tabular}{|c|c|c|c|c|c|}
\hline \multirow[b]{2}{*}{ Item } & \multirow[b]{2}{*}{ Equation } & \multicolumn{2}{|c|}{ Diet } & \multirow[b]{2}{*}{ SEM } & \multirow[b]{2}{*}{$P$ value } \\
\hline & & $\mathrm{LF}$ & $\mathrm{HF}$ & & \\
\hline Rumen volume, ${ }^{3} \mathrm{~L}$ & & 64.4 & 73.7 & 4.95 & 0.41 \\
\hline \multicolumn{6}{|l|}{ Rumen N pool, g } \\
\hline PCR & {$[1]$} & $7.18^{\mathrm{a}}$ & 27.4 & 1.57 & 0.01 \\
\hline Gravimetric & {$[2]$} & $18.3^{\mathrm{b}}$ & 28.1 & 1.57 & 0.05 \\
\hline \multicolumn{6}{|l|}{ Bacteria } \\
\hline PCR & [3] & 142 & 189 & 34.8 & 0.43 \\
\hline Gravimetric & [4] & 133 & 189 & 34.8 & 0.37 \\
\hline \multicolumn{6}{|l|}{ Duodenal flow, g/d } \\
\hline Total N & & 492 & 509 & 30.0 & 0.77 \\
\hline $\mathrm{DM}$ & & 1355 & 1351 & 0.88 & 0.99 \\
\hline \multicolumn{6}{|l|}{ Microbial N flow, g/d } \\
\hline \multicolumn{6}{|l|}{ Protozoa } \\
\hline PCR & [5] & $16.1^{\mathrm{a}}$ & $38.1^{\mathrm{a}}$ & 0.95 & 0.01 \\
\hline Gravimetric & {$[6]$} & $44.4^{\mathrm{b}}$ & $72.3^{\mathrm{b}}$ & 0.17 & 0.01 \\
\hline Gravimetric & [7] & $17.0^{\mathrm{a}}$ & $17.8^{\mathrm{c}}$ & 3.31 & 0.87 \\
\hline \multicolumn{6}{|l|}{ Bacteria } \\
\hline PCR & [8] & 255 & 282 & 21.2 & 0.53 \\
\hline
\end{tabular}

${ }^{a, b, c}$ Values within the same column and same item containing different superscripts differ.

${ }^{1} \mathrm{LF}=$ Low forage: $16 \%$ forage NDF; HF = high forage: $21 \%$ forage NDF.

${ }^{2}$ The probability of difference due to $\operatorname{diet}(\mathrm{n}=2)$.

${ }^{3}$ Mean rumen volume based on the 2-d rumen evacuation procedure (Harvatine et al., 2002b).

mented that the values might be underestimated by up to $30 \%$ because of efflux of small protozoa from their polyester filters with $17-\mu \mathrm{m}$ mesh and $10 \%$ open area. They based this assumption on 83 and $68 \%$ protozoal recovery for bags of 10 - and $20-\mu \mathrm{m}$ mesh (open area not disclosed), as reported by Neill and Ivan (1996). Although using similar pore sizes to ours (10 $\mu \mathrm{m})$, their agitation procedures seemed more rigorous than our dialysis procedure. Combining their more rigorous washing with a larger open area of their filter compared with ours (2\%), we would expect lower recovery of protozoal cells compared with our procedure (Sylvester et al., 2004). In our study, we did not determine actual recovery of protozoa from the filter bags; however, in numerous routine microscopic observations, we never detected a single protozoan in the dialysis washing steps. Our data (Table 4) are also consistent with predictions based on a mechanistic model of protozoal ecology (Dijkstra et al., 1998). For cattle fed $17.1 \mathrm{~kg} / \mathrm{d}$ of DMI, their model simulated an average of $21.6 \%$ protozoal $\mathrm{N}$ in the total microbial $\mathrm{N}$, with a range from 10.1 to $27.6 \%$. This percentage declined as DMI simulations increased, so at our higher DMI (24.5 $\mathrm{kg} / \mathrm{d}$ ), presumably with more rapid ruminal passage rates, we would expect a further predicted decline in protozoal $\mathrm{N}$ percentage from that model.

The bacterial $\mathrm{N}$ pool sizes were not different $(P>$ 0.5 ) among diets and averaged 142 and $189 \mathrm{~g}$ for LF and $\mathrm{HF}$ diets, respectively, determined by real-time PCR, compared with 133 and 189, respectively, deter- mined by the gravimetric procedure (Table 4). This method still assumes that all purines of dietary origin are completely degraded in the rumen. Although as much as $20 \%$ of the feed purines escape ruminal degradation, the much lower concentrations of $\mathrm{N}$ and RNA of feed compared with bacteria dilute this error to $5 \%$ or less (Calsamiglia et al., 1996). Future researchers should consider this and other issues with regard to validation of the purine assay in their laboratories (Firkins and Reynolds, 2005). The SE were higher relative to the means for the bacterial $\mathrm{N}$ pool sizes, as might be expected for a procedure that combines the errors from both the real-time PCR and purine assays.

Variances between methods were different $(P<0.06)$ when comparing duodenal flow of protozoal N; therefore, separate SEM are given for each method and were used to determine treatment differences (Table 4). The duodenal flow of protozoal $\mathrm{N}$ was lower $(P<$ $0.01)$ when cows were fed LF vs. HF when determined using the real-time PCR method. Similarly, when protozoal $\mathrm{N}$ pool size obtained using the gravimetric method was multiplied by either the passage rates per day of the ruminal fluid [6] or DNDF [7], these estimated duodenal flows of protozoal $\mathrm{N}$ were lower for LF than HF. The passage rate of DNDF was chosen because it explained much more of the difference in ruminal digestibilities of NDF in similar diets (Harvatine et al., 2002b) and because we reasoned that protozoa would be chemotactically attracted more to the DNDF than the indigestible NDF. Certain genera 
such as Epidinium, Isotricha, and Polyplastron are capable of temporary attachment to various substrates (Ankrah et al., 1990; Williams and Coleman, 1992), thus allowing them to associate with solid material and evade passage with the faster-passing ruminal fluid. For cows fed LF, the protozoal $\mathrm{N}$ flow determined using the real-time PCR procedure $(16.1 \mathrm{~g} / \mathrm{d})$ was similar to that estimated using the passage rate of DNDF $(17.0 \mathrm{~g} / \mathrm{d})$. Both were much lower than that estimated $(44.4 \mathrm{~g} / \mathrm{d})$ assuming protozoa pass entirely with the ruminal fluid. For cows fed $\mathrm{HF}$, the protozoal $\mathrm{N}$ flow determined using the real-time PCR procedure was in between that estimated using the passage rate of DNDF and that using the fluid dilution rate. Dijkstra et al. (1998) modeled the passage of protozoa to be half that of the solids dilution rate. Passage rate determined using rare earth markers, which was not measured in this study but has been used extensively in published reports, can migrate to small particles and fluid (Firkins et al., 1998) and often is up to 2 -fold higher than indigestible NDF. Using that model's parameters, we would therefore expect protozoal $\mathrm{N}$ passage (half of the solids passage rate) to approach the passage rate of indigestible NDF (half of rare earthdetermined passage rate). Thus, passage of protozoal $\mathrm{N}$ to the duodenum using the gravimetric method are in agreement with our expectations (similar to or higher than that estimated using [7]) based on this model of protozoal metabolism. The decreasing pool size and duodenal flow of the higher grain diet (LF) could be because of varying feed intake during the sampling period for cow 660 (data not shown) but also a result of lower ruminal $\mathrm{pH}$ (average of 6.18 for $\mathrm{LF}$ vs. 6.34 for HF; data not shown). At times during the feeding cycle, decreasing ruminal $\mathrm{pH}$ would be expected to be inhibitory to protozoa (Dehority, 2003). Moreover, the faster passage rates of DNDF for LF than $\mathrm{HF}$ ( 0.039 vs. $0.026 / \mathrm{h}$; data not shown) are indicative of a less firm ruminal mat to retain small feed particles and probably the protozoa feeding on them.

The net generation times of protozoal $\mathrm{N}$ calculated using the real-time PCR assay were 10.7 and $17.3 \mathrm{~h}$ for $\mathrm{LF}$ and $\mathrm{HF}$, respectively (pool size/duodenal flow $\times 24 \mathrm{~h} / \mathrm{d}$ ), explaining why relatively slow-growing protozoa represented a higher concentration of the total microbial $\mathrm{N}$ for HF. Although our average apparent generation times are somewhat shorter than those that others have determined (Dehority, 2003), those values generally were for sheep fed at lower maintenance intakes (Michalowski, 1998) or from various other indirect procedures (Dehority, 2003). With decreasing transfer interval as the criterion directly controlling the measurement of generation time, Dehority (1998) reported in vitro generation times for Epidi- nium (which was $>9 \%$ in cow 647 ) and Entodinium species (>98\% in cow 660 ) of $12 \mathrm{~h}$ (data from Sylvester et al., 2004). Williams and Withers (1993) determined apparent net generation times of 9 to $10 \mathrm{~h}$ in sheep. These net generation times are protozoa-doubling time corrected for cell lysis and recycling (Williams and Withers, 1993), both of which likely change with nutrient availability (Coleman, 1979; Dijkstra et al., 1998). Faster dilution rates for dairy cattle vs. sheep or nonlactating cattle (for most of the protozoa literature) should decrease recycling as fluid retention time approaches protozoal generation interval, as occurs for efficiency of bacterial growth (Firkins, 1996). The fluid dilution rates averaged 0.124 and $0.135 / \mathrm{h}$ for $\mathrm{LF}$ and HF $(P>0.10$; data not shown); fluid retention times (8.1 and $7.4 \mathrm{~h}$; reciprocals of fluid dilution rates) are somewhat shorter than what would be expected to maintain protozoal populations in the rumen, providing further support that protozoal $\mathrm{N}$ flow to the duodenum calculated using the gravimetric method with [6] is overestimated.

Unfortunately, the low $\mathrm{pH}$ of the abomasum completely lyses protozoal cells, so there was no independent, count-based procedure for us to verify our duodenal flow data. As discussed in our companion paper (Sylvester et al., 2004), low pH in the abomasum appeared to have no deleterious effects on recovery of protozoal rDNA (typically about $10^{8}$ copies $/ \mathrm{mL}$ ) in our current study. Further research quantifying omasal flow of protozoal cells would help evaluate our technique under more diverse dietary conditions.

Duodenal flow of bacterial $\mathrm{N}$ did not differ $(P>0.5)$ among diets (Table 4). The N:RNA ratios in bacteria were about 9.5 and $16.5 \%$ lower for bacteria than protozoa for LF and HF, respectively (calculated from data in Table 3). The standard method used in most research papers assumes negligible protozoal $\mathrm{N}$ or RNA in duodenal digesta because only a bacterial standard is used. Thus, using only bacterial N:RNA ratios would bias the determination of total microbial $\mathrm{N}$ progressively with more protozoal $\mathrm{N}$ flowing to the duodenum and with more divergent N:RNA ratios in bacteria vs. protozoa. Using N:RNA data in protozoa and bacteria from Firkins et al. (1987a, 1987b) and an estimated $41 \%$ of microbial $\mathrm{N}$ as protozoal $\mathrm{N}$ (Firkins et al., 1987a), we calculated that total microbial $\mathrm{N}$ flow and microbial $\mathrm{N}$ pool could be underestimated by as much as 13 and 20\%, respectively, if protozoal N:RNA is ignored. Without reliable protozoal markers, the degree of error in studies ignoring protozoal contribution of microbial markers is hard to assess.

$D G G E$ banding patterns of ruminal and duodenal digesta. The counts or generic distributions of protozoa were not significantly affected by diet, al- 


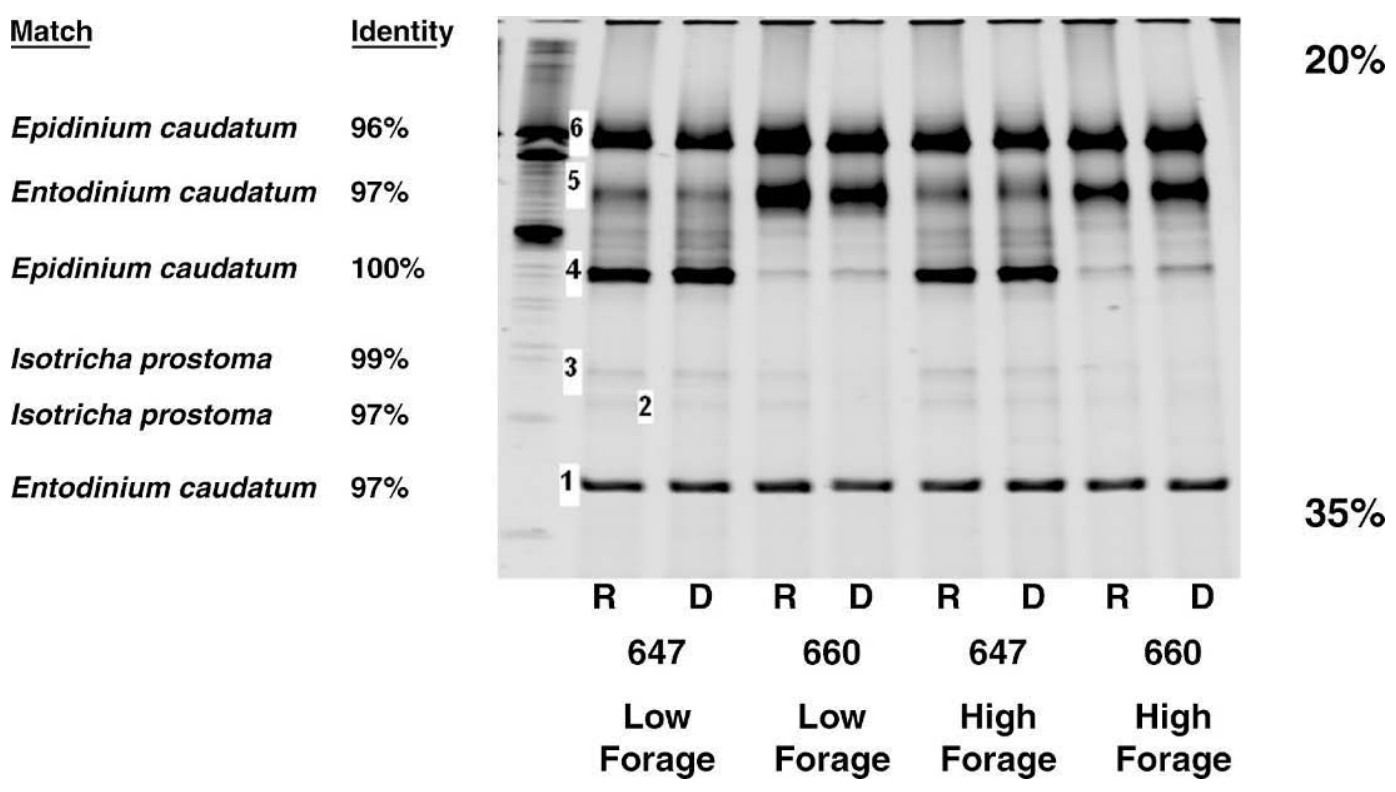

Figure 2. Denaturing gradient gel electrophoresis profiles (20 to 35\% gradient) and highest sequence identity produced by set 1 (1320f$1617 \mathrm{r}$ ) comparing rumen (R) and duodenal (D) samples of 2 cows (647 and 660) fed 2 diets (low and high forage).

though differences in protozoal genera among animal were detected (Sylvester et al., 2004). The most notable difference was that cow 660 contained up to $15 \%$ Epidinium, but none were observed in cow 647 . There were numeric increases (20\%; data not shown) in protozoal counts on the HF diet that support the larger protozoal $\mathrm{N}$ pool sizes (Table 4).

The rDNA ranged from 1010 to 6210 copies per protozoal cell (data not shown). For cows fed HF, the mean rDNA copies per protozoal cell were very similar when determined from either ruminal fluid or from the filtered protozoa samples, averaging 6210 and 6140 for cow 647 and 1790 and 1870 for cow 660, respectively. When fed LF, however, mean rDNA copies per protozoal cell were somewhat lower for the ruminal fluid compared with the protozoal standard, averaging 1940 and 4370 for cow 647 and 1010 and 2730 for cow 660 . To our knowledge, no data for ruminal protozoa have been reported, although the nonrumen protozoan Tetrahymena maintained about 9000 copies of rDNA per cell (Blomberg et al., 1997) and the ratio of rDNA/total genomic DNA should increase during rapid growth (Larson et al., 1991). If rDNA copies per cell were adjusted to the lower values for ruminal fluid, ruminal pool size and duodenal flow would be increased for LF. We are investigating how substrate availability and time after feeding affects rDNA copies per cell to explain these effects and for potential improvements in accuracy of our assay. However, our previous work seemed to rule out effects of PCR inhibitors or differ- ences in amplification efficiencies with varying amounts of template (Sylvester et al., 2004).

Denaturing gradient gel electrophoresis is a cultureindependent method that has been used to study ecology of ruminal bacteria (Kocherginskaya et al., 2001) and nonrumen protozoa (Rasmussen et al., 2001). More recently, Regensbogenova et al. (2004) have adapted DGGE analysis to ruminal protozoa. This analysis is semiquantitative, subject to PCR biases, and requires cloning for identification of bands (Zoetendal et al., 2004). However, sequencing was done to identify bands, and PCR bias seems much less likely for protozoa than for bacteria because the latter are much more diverse (Kocherginskaya et al., 2001), whereas ruminal protozoa are monophyletic (Mackie et al., 2000; Dehority, 2003). Mackie et al. (2000) concluded that DGGE is a very useful procedure to monitor microbial population shifts.

Distinct DGGE banding patterns were obtained, with primer set 1 producing 5 major bands (Figure 2) and primer set 2 producing 11 major bands (Figure 3 ). Because a threshold amount of rDNA needs to be amplified for bands to be distinguished, these bands represent the most abundant protozoal species. Sequence analysis supports the diversity of abundant phylotypes represented by DGGE bands and generally matches well with protozoal counts (Sylvester et al., 2004). For example, band 4 in Figure 2 and band 6 in Figure 3 are seen for cow 647 but barely visualized for cow 660, which is expected based on the high abun- 


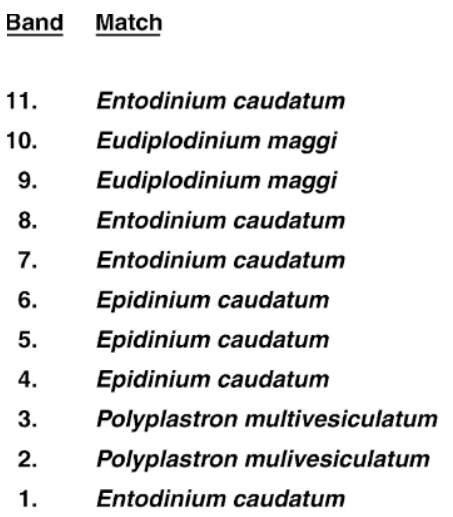

Identity
$97 \%$
$95 \%$
$96 \%$
$98 \%$
$97 \%$
$100 \%$
$99 \%$
$95 \%$
$99 \%$
$95 \%$
$97 \%$

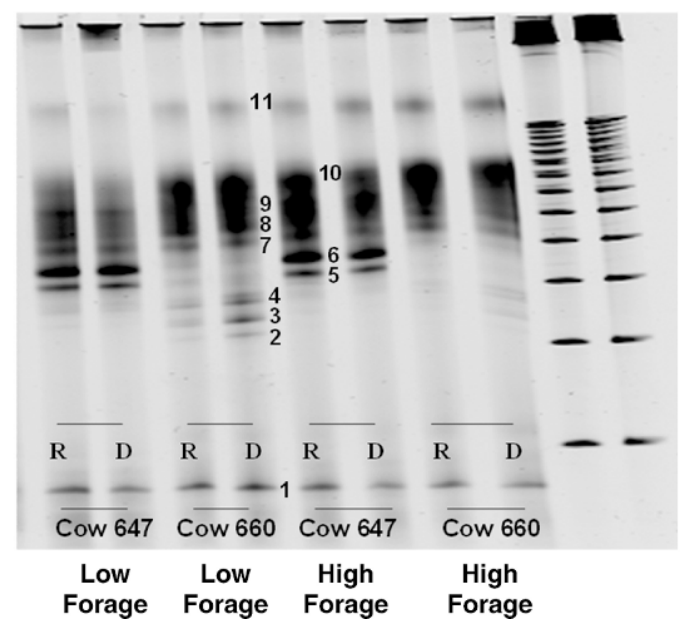

Figure 3. Denaturing gradient gel electrophoresis profiles ( 28 to $43 \%$ gradient) and highest sequence identity produced by set 2 (316f539r) comparing rumen (R) and duodenal (D) samples of 2 cows fed 2 diets (low and high forage).

dance of Epidinium counts in 647 but not in 660 (Sylvester et al., 2004). As sequence identity decreases below $99 \%$, the band identity becomes progressively difficult to resolve because of the high degree of homology between rumen protozoa. More $18 \mathrm{~S}$ rDNA sequencing of functionally important (but not previously sequenced) protozoal species for deposition in GenBank (Benson et al., 2004) would help further characterize protozoal populations from the $\geq 94 \%$ sequence identity closer to true species identification.

Although multiple sequences representing different species migrated together during DGGE analysis for bacteria (Kocherginskaya et al., 2001), we decreased the range of denaturing gradients to achieve maximum band separation. Consistent high quality electrophoretogram traces (User Guide, 3730 DNA Analyzer, Applied Biosystem, Inc. Foster City, CA) obtained during DNA sequencing (i.e., single, sharp peaks) were interpreted to suggest that single PCR products represented each distinct band. Banding patterns and sequences obtained from companion gels gave identical conclusions (data not shown), providing additional confidence that DGGE analysis can be reliably used to study protozoal ecology in dairy cattle.

The DGGE banding profiles generally were much more similar between the ruminal and duodenal samples within each respective animal than when compared across animals. Similar distributions of protozoal populations in the rumen and omasum (Towne and Nagaraja, 1990; Punia and Leibholz, 1994; Michalowski, 1998) further support our conclusion based on DGGE profiles that the filtration method accurately represents the actual protozoal populations of both the ruminal fluid and duodenal digesta; thus, the proto- zoal standard collected from the rumen appears to be satisfactory to adjust copies of protozoal rDNA to grams of protozoal $\mathrm{N}$ for both sites (Table 4).

\section{CONCLUSIONS}

Using our modified filtration method, contamination of protozoal standards with bacteria has minimal effects on reference $\mathrm{N}$ and RNA values. Based on the DGGE data, the use of protozoal cells isolated from ruminal fluid seems appropriate for quantitative assays determining protozoal $\mathrm{N}$ flow postruminally. Our objectives were to provide in vivo evaluation of the accuracy of the procedure as well as estimates of experimental variation needed to design future experiments. Using real-time PCR targeting protozoal rDNA, protozoal $\mathrm{N}$ was determined to be 4.8 and $12.7 \%$ of the rumen microbial $\mathrm{N}$ pool and 5.9 and $11.9 \%$ of the duodenal $\mathrm{N}$ flow for cows fed diets containing low (16\%) or higher $(21 \%)$ forage NDF diets. These data are similar to expected values and to values estimated independently using protozoal count data. However, more in vivo data are needed using larger numbers of animals fed diets containing ingredients known to affect protozoal populations to evaluate the robustness of the procedure.

\section{ACKNOWLEDGMENTS}

The authors thank Milton Lima for his help managing the animals, collecting samples, and recruiting volunteers for rumen evacuation and Normand St-Pierre for his statistical advice. 


\section{REFERENCES}

Ahvenjärvi, S., A. Vanhatalo, and P. Huhtanen. 2002. Supplementing barley or rapeseed meal to dairy cows fed grass-red clover silage. I. Rumen degradability and microbial flow. J. Anim. Sci. 80:2176-2187.

Altscul, S. F., W. Gish, W. Miller, E. W. Myers, and D. J. Lipman. 1990. Basic local alignment search tool. J. Mol. Biol. 215:403410.

Ankrah, P., S. C. Loerch, and B. A. Dehority. 1990. Sequestration, migration and lysis of protozoa in the rumen. J. Gen. Microbiol. 136:1869-1875.

Benson, D. A., I. Karsch-Mizrachi, D. J. Lipman, J. Ostell, and D. L. Wheeler. 2004. GenBank. Update. Nucleic Acids Res. 32:D23-D26.

Berndtson, W. E. 1991. A simple, rapid and reliable method for selecting or assessing the number of replicates for animal experiments. J. Anim. Sci. 69:67-76.

Blomberg, P., C. Randolph, C.-H. Yao, and M.-C. Yao. 1997. Regulatory sequences for the amplification and replication of the ribosomal DNA minichromosome in Tetrahymena thermophila. Mol. Cell. Biol. 17:7237-7247.

Broderick, G. A., and N. R. Merchen. 1992. Markers for quantifying microbial protein synthesis in the rumen. J. Dairy Sci. 75:2618-2632.

Callison, S. L., J. L. Firkins, M. L. Eastridge, and B. L. Hull. 2001. Site of nutrient digestion by dairy cows fed corn of different particle sizes or steam-rolled. J. Dairy Sci. 84:1458-1467.

Calsamiglia, S., M. D. Stern, and J. L. Firkins. 1996. Comparison of nitrogen-15 and purines as microbial markers in continuous culture. J. Anim. Sci. 74:1375-1381.

Clark, J. H., T. H. Klusmeyer, and M. R. Cameron. 1992. Microbial protein synthesis and flows of nitrogen fractions to the duodenum of dairy cows. J. Dairy Sci. 75:2304-2323.

Coleman, G. S. 1979. The role of rumen protozoa in the metabolism of ruminants given tropical feeds. Trop. Anim. Prod. 4:199-212.

Dehority, B. A. 1993. Laboratory manual for classification and morphology of rumen ciliate protozoa. CRC Press, Inc., Boca Raton, FL.

Dehority, B. A. 1998. Generation times of Epidinium caudatum and Entodinium caudatum, determined in vitro by transferring at various time intervals. J. Anim. Sci. 76:1189-1196.

Dehority, B. A. 2003. Rumen Microbiology. Nottingham University Press, Nottingham, UK.

Dijkstra, J., J. France, and S. Tamminga. 1998. Quantification of the recycling of microbial nitrogen in the rumen using a mechanistic model of rumen fermentation processes. J. Agric. Sci. 130:81-94.

Firkins, J. L. 1996. Maximizing microbial protein synthesis in the rumen. J. Nutr. 126:1347S-1354S.

Firkins, J. L., M. S. Allen, B. S. Oldick, and N. R. St-Pierre. 1998. Modeling ruminal digestibility of carbohydrates and microbial protein flow to the duodenum. J. Dairy Sci. 81:3350-3369.

Firkins, J. L., L. L. Berger, N. R. Merchen, G. C. Fahey, and R. L. Mulvaney. 1987a. Ruminal nitrogen metabolism in steers as affected by feed intake and dietary urea concentration. J. Dairy Sci. 70:2302-2311.

Firkins, J. L., S. M. Lewis, L. Montgomery, L. L. Berger, N. R. Merchen, and G. C. Fahey. 1987b. Effects of feed intake and dietary urea concentration on ruminal dilution rate and efficiency of bacterial growth in steers. J. Dairy Sci. 70:2312-2321.

Firkins, J. L., and C. K. Reynolds. 2005. Whole animal nitrogen balance in cattle. Pages 167-185 in Nitrogen and Phosphorus Nutrition of Cattle and Environment. A. N. Hristov and E. Pfeffer, ed. CAB International, Wallingford, UK.

Harvatine, D. I., J. L. Firkins, and M. L. Eastridge. 2002a. Whole linted cottonseed as a forage substitute fed with ground or steamflaked corn: Digestibility and performance. J. Dairy Sci. 85:1976-1987.

Harvatine, D. I., J. E. Winkler, M. Devant-Guille, J. L. Firkins, N. R. St-Pierre, and M. L. Eastridge. 2002b. Whole linted cottonseed as a forage substitute: Fiber effectiveness and digestion kinetics. J. Dairy Sci. 85:1988-1999.
Ivan, M., L. Neill, and T. Entz. 2000. Ruminal fermentation and duodenal flow following progressive inoculations of fauna-free wethers with major individual species of ciliate protozoa or total fauna. J. Anim. Sci. 78:750-759.

Jouany, J. P. 1996. Effect of rumen protozoa on nitrogen utilization by ruminants. J. Nutr. 126:1335S-1346S.

Klieve, A. V., D. Hennessey, D. Ouwerkerk, R. J. Forster, R. I. Mackie, and G. T. Attwood. 2003. Establishing populations of Megasphaera elsdenii YE34 and Butyrivibrio fibrisolvens YE44 in the rumen of cattle fed high grain diets. J. Appl. Microbiol. 95:621-630.

Kocherginskaya, S., R. I. Aminov, and B. A. White. 2001. Analysis of the rumen bacterial diversity under two different diet conditions using denaturing gradient gel electrophoresis, random sequencing, and statistical ecology approaches. Anaerobe 7:119-134.

Larson, D. D., A. R. Umthun, and W.-L. Shaiu. 1991. Copy number control in Tetrahymena macronuclear genome. J. Protozool. 38:258-263.

Leng, R. A., and J. V. Nolan. 1984. Nitrogen metabolism in the rumen. J. Dairy Sci. 67:1072-1089.

Lima, M. L. M., J. L. Firkins, J. T. Sylvester, S. K. R. Karnati, and W. Mattos. 2003. Physical effectiveness of whole cottonseed as affected by lint and particle size. J. Dairy Sci. 86(Suppl. 1):64. (Abstr.)

Mackie, R. I., R. I. Aminov, B. A. White, and C. S. McSweeney. 2000. Molecular ecology and diversity in gut microbial ecosystems. Page 61-77 in Ruminant Physiology. Digestion, Metabolism, Growth, and Reproduction. P. B. Cronjé, ed. CABI Publishing, New York, NY.

Martin, C., A. G. Williams, and B. Michalet-Doreau. 1994. Isolation and characteristics of the protozoal and bacterial fractions from bovine ruminal contents. J. Anim. Sci. 72:2962-2968.

Michalowski, T. 1998. A proposed simple method for determining the outflow of ciliates from the reticulo-rumen. J. Anim. Feed Sci. 7:83-92.

National Research Council. 2001. Nutrient Requirements of Dairy Cattle. 7th rev. ed. ed. Natl. Acad. Sci., Washington, DC.

Neill, L., and M. Ivan. 1996. Comparison of methods for isolation of protozoa from ruminal fluid. Can. J. Anim. Sci. 76:481-483.

Punia, B. S., and J. Leibholz. 1994. Effect of level of intake of kikuyu (Pennisetum clandestinum) grass hay on the flow of protozoal nitrogen to the omasum of cattle. Anim. Feed Sci. Technol. 47:77-87.

Rasmussen, L. D., F. Ekelund, L. H. Hansen, and K. Johnsen. 2001. Group-specific PCR primers to amplify $24 \mathrm{~S} \alpha$-subunit rRNA genes from Kinetoplastida (protozoa) used in denaturing gradient gel electrophoresis. Microb. Ecol. 42:109-115.

Regensbogenova, M., P. Pristas, P. Javorsky, S. Y. Moon-van der Staay, G. W. M. van der Staay, J. H. P. Hackstein, C. J. Newbold, and N. R. McEwan. 2004. Assessment of ciliates in the sheep rumen by DGGE. Lett. Appl. Microbiol. 39:144-147.

SAS Institute. 1999. What's New in SA Software for Version 7 and the Version 8 Developer's Release. Release 7 ed. SAS Inst., Cary, NC.

Shabi, Z., H. Tagari, M. R. Murphy, I. Bruckental, S. J. Mabjeesh, S. Zamwell, K. Celik, and A. Arieli. 2000. Partitioning of amino acids flowing to the abomasum into feed, bacterial, protozoal, and endogenous fractions. J. Dairy Sci. 83:2326-2334.

Sharp, R., C. J. Ziemer, M. D. Stern, and D. A. Stahl. 1998. Taxonspecific associations between protozoal and methanogen populations in the rumen and a model rumen system. FEMS Microbiol. Ecol. 26:71-78

Soliva, C. R., L. Meile, M. Kreuzer, and A. Machmüller. 2004. Rumen simulation technique study on the interactions of dietary lauric and myristic acid supplementation in suppressing ruminal methanogenesis. Br. J. Nutr. 92:689-700.

Steinhour, W. D., M. R. Stokes, J. H. Clark, J. A. Rogers, and C. L. Davis. 1982. Estimation of the proportion of non-ammonianitrogen reaching the lower gut of the ruminant derived from bacterial and protozoal nitrogen. Br. J. Nutr. 48:417-431.

Sylvester, J. T., S. K. R. Karnati, Z. Yu, M. Morrison, and J. L. Firkins. 2004. Development of an assay to quantify rumen ciliate 
protozoal biomass in cows using real-time PCR. J. Nutr. 134:3378-3384.

Towne, G., and T. G. Nagaraja. 1990. Omasal ciliated protozoa in cattle, bison, and sheep. Appl. Environ. Microbiol. 56:409-412.

Uden, P., P. E. Colucci, and P. J. Van Soest. 1980. Investigation of chromium, cerium and cobalt as markers in digesta rate of passage studies. J. Sci. Food Agric. 31:625-632.

Ushida, K., B. Lassalas, and J. P. Jouany. 1985. Determination of assay parameters for RNA analysis in bacterial and duodenal samples by spectrophotometry. Influence of sample treatment and preservation. Reprod. Nutr. Dev. 25:1037-1046.

Volden, H., L. T. Mydland, and O. M. Harstad. 1999. Chemical composition of protozoal and bacterial fractions isolated from ruminal contents of dairy cows fed diets differing in nitrogen supplementation. Acta Agric. Scand. A Anim. Sci. 49:235-244.

Williams, A. G., and G. S. Coleman. 1992. The Rumen Protozoa. Springer-Verlag, New York, NY.
Williams, A. G., and S. E. Withers. 1993. Changes in the rumen microbial population and its activities during the refaunation period after the reintroduction of ciliate protozoa into the rumen of defaunated sheep. Can. J. Microbiol. 39:61-69.

Williams, C. H., D. J. David, and O. Iismaa. 1962. The determination of chromic oxide in feces samples by atomic absorption spectrophotometry. J. Agric. Sci. 59:381-385.

Yu, W., W. K. Dodds, M. K. Banks, J. Skalsky, and E. A. Strauss. 1995. Optimal staining and sample storage time for direct microscopic enumeration of total and active bacteria in soil with two fluorescent dyes. Appl. Environ. Microbiol. 61:3367-3372.

Zinn, R. A., and F. N. Owens. 1986. A rapid procedure for purine measurement and its use for estimating net ruminal protein synthesis. Can. J. Anim. Sci. 66:157-166.

Zoetendal, E. G., C. T. Collier, S. Koike, R. I. Mackie, and H. R. Gaskins. 2004. Molecular ecological analysis of the gastrointestinal microbiota: A review. J. Nutr. 134:465-472. 